\title{
Carbon capture and long-term storage in basalt of the Deccan volcanic province: a possible device to control climate change
}

\author{
AMIT KUMAR*1,2 ${ }^{*}$ J. P. SHRIVASTAVA ${ }^{1}$ AND RAJESH K. \\ SRIVASTAVA ${ }^{2}$ \\ ${ }^{1}$ Department of Geology, Univcersity of Delhi, Delhi 110007 , \\ India \\ ${ }^{2}$ Centre of Advanced Study in Geology, Institute of Science, \\ Banaras Hindu University, Varanasi 221005, India
}

The Deccan volcanic province in India provide most suitable conditions for carbon capture and storage as: (a) they represents vast accumulations of $\mathrm{Fe}$ - and $\mathrm{Mg}$-rich lava flows, (b) large and continuous areal extent along-with an combined thickness $(>1 \mathrm{~km}$ in few localities) of lava flows and (c) favourable inter-flow features. Previous water- $\mathrm{CO}_{2}$ interaction studies were focused on pyroxene, olivine and plagioclase reaction rates; however, limited research has examined the Deccan basalt. Therefore, basalt- $\mathrm{CO}_{2}$-watersaturated interaction experiments and numerical simulations were performed under hydrothermal-like conditions (at 100 ${ }^{\circ} \mathrm{C}$ under 5 and 10 bar $\mathrm{pCO}_{2}$ for 50-1000 hours). Gibb's free energy, enthalpy and entropy represent the feasibility of plgioclase, pyroxene and magnetite dissolution and calcite, ankerite and siderite formation. Congruently, short duration experiments revealed formation of neo-formed carbonates (e.g., calcite $>$ ankerite $>$ siderite) that predominated over silicates (e.g., saponite $>$ chabazite $>$ chlorite), however, with increase in reaction time, carbonates no longer persisted in the system as they were replaced by silicates. Rietveld refinement results indicate that large spontaneous strain within calcite led to contraction along c-axis and expansion along a-axis. Increase in $\mathrm{C}-\mathrm{O}$ bond length facilitated deterioration of calcite structure, thus, no calcite persisted in the system beyond $80 \mathrm{~h}$ of experiments. The mass balance estimates in leachate after each experiment run revealed that the maximum $\mathrm{CO}_{2}(\sim 38 \%)$ is mineralized from the ions derived from the parent basalt at $100{ }^{\circ} \mathrm{C}$ under 5 bar $\mathrm{CO} 2$ and $70 \mathrm{~h}$ of experiment run.

Carbonates form with marked changes in cell parametric and inter-atomic values and influenced mainly by the time; however, $\mathrm{pCO}_{2}$ and temperature play subordinate role.

Keywords: Basalt; Cartbon capture and storag; Deccan volcanic province; Mass balance; Numerical simulation models; Rietveld refinement 